\title{
CUCKOO AND FOX SPARROW
}

William Niven, Sheho

Birds of most species were more plentiful in mid-winter than they were last year. After the count was taken last year, I found out why the Pine Grosbeaks were so scarce. Large flocks of them, in the hundreds, were feeding on fields of flax-seed left standing in some places owing to the early approach of winter. Also still larger numbers of Common Redpolls were on the same fields in thousands. This was something new as the Pine Grosbeaks generally feed on the Snowberries and Redpolls on different field weed seeds. It proves they are adaptable to change of diet, when such is available. This winter no grain of any kind is left standing in the fields, so they are on their usual fare.

Arthur Ward, of Swift Current, wishes information on the Blackbilled Cuckoo and the Fox Sparrow - the former which has disappeared from his district, and the Fox Sparrow which has never been seen there. Both of these birds seem to have their cycles of abundance and times when they are entirely absent here.
The Cuckoo was for years quite plentiful here nesting in summer, though they are very late arriving. Then for years they disappeared altogether. The last three or four years they have returned again, but in much smaller numbers. I believe only one was heard last summer. According to Taverner, they feed on hairy caterpillars and their numbers increase with the insects, but I cannot say whether this is the case or not.

The Fox Sparrow, I believe, only nests in the northern forests. Many years ago it use to be see in fairly large numbers in spring, staying for a week or two along with Juncoes and Tree Sparrows. For many weeks none passed through here. The last couple of years a very few have been noted. One was seen and heard singing from the top of a willow. The male has a beautiful song, loud and clear-better than any of the sparrows-more like the warble of the Purple Finch or Robin. In spring they are a fine foxy red on the back. They have a white breast with large dark spots.

\section{A Bird in the Bush}

By Marianne E. Clark, Woodcock, B.C.

\section{A little Wilson Warbler}

Comes to my lilac bush.

His cap could not be blacker

And his coat is greenish plush.

His breast is lemon yellow,

And he's really quite a fellow

As he flits and goes aflutter

In the lilac bush.

Oh! he's up and down and over,

Then on another tack

Where he scans a plant of clover

Then round again, and back,

And he pries the leave asunder-

Always searching for his plunder,

Every fold and crack.
In the early, early morning When everything's a'hush,

When spring time is a'borning And the eastern sky's a'flush,

Then you see him hopping - seaching

Skipping - flying - perching

In the lilac bush. 